\title{
Total alkalinity: The explicit conservative expression and its application to biogeochemical processes
}

\author{
Dieter A. Wolf-Gladrow ${ }^{\mathrm{a}, *}$, Richard E. Zeebe ${ }^{\mathrm{a}, 1}$, Christine Klaas ${ }^{\mathrm{a}}$, \\ Arne Körtzinger ${ }^{\mathrm{a}, 2}$, Andrew G. Dickson ${ }^{\mathrm{a}, \mathrm{b}}$ \\ ${ }^{a}$ Alfred Wegener Institute for Polar and Marine Research, Postfach 1201 61, D-27515 Bremerhaven, Federal Republic of Germany \\ ${ }^{\mathrm{b}}$ Marine Physical Laboratory, Scripps Institution of Oceanography, University of California, San Diego, 9500 Gilman Drive, \\ La Jolla, CA 92093-0244, USA
}

Received 13 February 2006; received in revised form 15 September 2006; accepted 4 January 2007

Available online 26 January 2007

\begin{abstract}
Total alkalinity (TA) is one of the few measurable quantities that can be used together with other quantities to calculate concentrations of species of the carbonate system $\left(\mathrm{CO}_{2}, \mathrm{HCO}_{3}^{-}, \mathrm{CO}_{3}^{2-}, \mathrm{H}^{+}, \mathrm{OH}^{-}\right)$. TA and dissolved inorganic carbon (DIC) are conservative quantities with respect to mixing and changes in temperature and pressure and are, therefore, used in oceanic carbon cycle models. Thus it is important to understand the changes of TA due to various biogeochemical processes such as formation and remineralization of organic matter by microalgae, precipitation and dissolution of calcium carbonate. Unfortunately deriving such changes from the common expression for TA in terms of concentrations of non-conservative chemical species $\left(\mathrm{HCO}_{3}^{-}, \mathrm{CO}_{3}^{2-}\right.$, $\mathrm{B}(\mathrm{OH})_{4}^{-}, \mathrm{H}^{+}, \mathrm{OH}^{-}$, etc.) is rarely obvious.

Here an expression for TA $\left(\mathrm{TA}_{\mathrm{ec}}\right)$ in terms of the total concentrations of certain major ions $\left(\mathrm{Na}^{+}, \mathrm{Cl}^{-}, \mathrm{Ca}^{2+}\right.$ etc.) and the total concentrations of various acid-base species (total phosphate etc.) is derived from Dickson's original definition of TA under the constraint of electroneutrality. Changes of TA by various biogeochemical processes are easy to derive from this so-called explicit conservative expression for TA because each term in this expression is independent of changes of temperature or pressure within the ranges normally encountered in the ocean and obeys a linear mixing relation.

Further, the constrains of electroneutrality for nutrient uptake by microalgae and photoautotrophs are discussed. A so-called nutrient- $H^{+}$-compensation principle is proposed. This principle in combination with $\mathrm{TA}_{\mathrm{ec}}$ allows one to make predictions for changes in TA due to uptake of nutrients that are consistent with observations. A new prediction based on this principle is the change in TA due to nitrogen fixation followed by remineralization of organic matter and subsequent nitrification of ammonia which implies a significant sink of TA in tropical and subtropical regions where most of the nitrogen fixation takes place.
\end{abstract}

(C) 2007 Published by Elsevier B.V.

Keywords: Proton acceptors; Proton condition; Electroneutrality; Calcification; Nitrogen fixation; Remineralization

\footnotetext{
* Corresponding author. Fax: +49 47148311425.

E-mail addresses: Dieter.Wolf-Gladrow@awi.de (D.A. Wolf-Gladrow), zeebe@soest.hawaii.edu (R.E. Zeebe), Christine.Klaas@awi.de (C. Klaas), akoertzinger@ifm-geomar.de (A. Körtzinger), adickson@ucsd.edu (A.G. Dickson).

${ }^{1}$ Current address: Department of Oceanography, University of Hawai‘ at Manoa, 1000 Pope Road, Marine Sciences Building, Honolulu, HI 96822.

${ }^{2}$ Current address: Leibniz Institut für Meereswissenschaften, Düsternbrooker Weg 20, D-24105 Kiel, Federal Republic of Germany.
} 


\section{Introduction}

Total alkalinity is an important and very useful concept in the context of the carbonate system in seawater. Already in the 19th century it was known that seawater is alkaline and that it contains large amounts of dissolved inorganic carbon (DIC) which can be released in the form of $\mathrm{CO}_{2}$ by titration with a strong acid. The alkalinity of seawater is much higher than that of freshwater and so is the content of DIC. Although several authors (for example, Jacobsen, 1873) supposed a connection between salt and DIC, the development of a clear concept of alkalinity had to await progress in understanding the form of salts in aqueous solutions (ions instead of undissociated compounds) and an advanced concept of acids and bases (proton donors and acceptors; Brønsted, 1923; Lowry, 1923a,b). In the 1930s alkalinity was defined operationally as the number of milliequivalents of hydrogen ion neutralized by one liter of water at $20^{\circ} \mathrm{C}$, without detailing which chemical species are actually responsible for the observed neutralization. Rakestraw (1949) was the first to discuss how the 'concept of proton donors and acceptors could be used to shed light on exactly what it was that an alkalinity titration measured' (Dickson, 1992). Rakestraw's expression, which considered only bicarbonate, carbonate ion and borate, is still a first approximation to the most recent definition by Dickson (1981), cf. DOE (1994). The historical development of the alkalinity concept is discussed in detail by Dickson (1992). Even today several different definitions of TA are in use and can be found in textbooks: a fact that may lead to confusion. The concept of TA has been characterized as difficult to grasp and to explain.

The plan of the current paper is as follows. In Section 2 we consider a system with simple chemical composition where the alkalinity concept is easily explained. Based on the understanding of this system we discuss the generalization of the TA concept and hence Dickson's definition. Dickson's expression for TA in natural water samples is given in Section 3.11. The combination of Dickson's expression for alkalinity with the expression for the charge balance (electroneutrality) of the solution leads to an expression for TA in terms of conservative species and conservative total concentrations (Section 4). Although this expression is easy to derive, it has not been published before, to the best of our knowledge, and is very useful to calculate changes in alkalinity due to various biogeochemical processes (Section 5). An alternative definition of TA proposed by Peng et al. (1987) and its relation to Dickson's definition is discussed in Section 6.
All concentrations in the current paper are assumed to be on the moles per kilogram solution scale (gravimetric units; mol kg-1 for short). The use of gravimetric units has the advantage that concentrations of quantities such as DIC or $\left[\mathrm{Na}^{+}\right]$stay constant despite changes of pressure or temperature.

In marine chemistry the term 'conservative' quantity or property has been used in various, often contradictory, ways. Quantities have been denoted as conservative without explaining in what sense. Distinct definitions are legitimate and reflect the interests of different communities. In order to avoid confusion we will define the concept of 'conservative quantities' as used in this article. When two water parcels are mixed together the amount of any chemical element, $E$, in the mixture is equal to the sum of the amounts of this element in the two initial parcels and thus the concentration of $E$ measured in gravimetric units obeys the linear mixing relation

$[E]_{1} M_{1}+[E]_{2} M_{2}=[E]_{m}\left(M_{1}+M_{2}\right)$

where $[E]_{s}$ is the concentration of element $E$ in parcel $s=1$, $s=2$, or in the mixture $(s=m)$ and $M_{s}$ are the corresponding masses. This linear mixing relation can be used to calculate $[E]_{m}$. Quantities that obey this linear mixing relation and stay constant under changes of temperature $(T)$ and pressure $(p)$ will be called 'conservative with respect to mixing and changes in $T$ or $p$ ' or just 'conservative'.

Thus DIC is conservative because the carbon atoms of DIC stay as DIC during mixing and changes of temperature and pressure. The same applies to total phosphate because the phosphorus atoms are still in one or the other form of phosphate after mixing or changes in $T$ or $p$. The total concentrations of other acid-base systems such as total ammonia and total sulphate are conservative as well. The concentrations of ions such as $\mathrm{Na}^{+}, \mathrm{Ca}^{2+}, \mathrm{Cl}^{-}, \mathrm{NO}_{3}^{-}$etc. are also conservative because they are derived from fully dissociated acids or bases. TA is conservative too; this will become obvious later.

In contrast to DIC and TA, the concentrations of individual species of the carbonate system change with temperature and pressure (because of variation of the equilibrium constants with $T$ and $p$ ). Even if $T, p$, and $S$ of two water parcels are equal, the concentrations of $\mathrm{CO}_{2}, \mathrm{HCO}_{3}^{-}$, and $\mathrm{CO}_{3}^{2-}$ do not obey a linear mixing relation if their concentrations in the initial water parcels are different.

\section{Total alkalinity in a simple system}

In order to get a feeling for the alkalinity concept we will discuss total alkalinity in a simplified seawater 
system made up from $\mathrm{NaCl}, \mathrm{NaHCO}_{3}, \mathrm{CO}_{2}$, and $\mathrm{H}_{2} \mathrm{O}$. Our simplified seawater contains $\mathrm{H}_{2} \mathrm{O}, \mathrm{H}^{+}, \mathrm{OH}^{-}, \mathrm{Na}^{+}$, $\mathrm{Cl}^{-}, \mathrm{CO}_{2}, \mathrm{HCO}_{3}^{-}$, and $\mathrm{CO}_{3}^{2-}$ only. The observed conditions are $\left[\mathrm{Na}^{+}\right]=0.6 \mathrm{~mol} \mathrm{~kg}^{-1}$, DIC $=2 \mathrm{mmol} \mathrm{kg}$, $\mathrm{pH}=8.2$, and $T_{\mathrm{C}}=25^{\circ} \mathrm{C}$. The following $\mathrm{pK}$ values will be used (the star as superscript denotes stoichiometric in contrast to thermodynamic equilibrium constant; compare, for example, Zeebe and Wolf-Gladrow, 2001, for a discussion of equilibrium constants): $\mathrm{pK}_{\mathrm{W}}^{*}=13.2$ (ion product of water), $\mathrm{pK}_{1}^{*}=5.9, \mathrm{pK}_{2}^{*}=8.9$ (first and second dissociation constant of carbonic acid). The concentrations of $\mathrm{H}^{+}\left(6.3 \cdot 10^{-3} \mu \mathrm{mol} \mathrm{kg} \mathrm{kg}^{-1}\right), \mathrm{OH}^{-}$ (10 $\left.\mu \mathrm{mol} \mathrm{kg} \mathrm{kg}^{-1}\right), \mathrm{CO}_{2}\left(8.3 \mu \mathrm{mol} \mathrm{kg} \mathrm{kg}^{-1}\right), \mathrm{HCO}_{3}^{-}$ $\left(1660 \mu \mathrm{mol} \mathrm{kg}{ }^{-1}\right)$, and $\mathrm{CO}_{3}^{2-}\left(331 \mu \mathrm{mol} \mathrm{kg}{ }^{-1}\right)$ can be calculated from the initial values and $\mathrm{pK}^{*}$ values as follows:

$$
\begin{aligned}
& {\left[\mathrm{H}^{+}\right]=10^{-\mathrm{pH}}, \mathrm{OH}^{-}=\frac{K_{\mathrm{W}}^{*}}{\left[\mathrm{H}^{+}\right]}} \\
& {\left[\mathrm{CO}_{2}\right]=\mathrm{DIC} \frac{\left[\mathrm{H}^{+}\right]^{2}}{\left[\mathrm{H}^{+}\right]^{2}+\left[\mathrm{H}^{+}\right] K_{1}^{*}+K_{1}^{*} K_{2}^{*}}} \\
& {\left[\mathrm{HCO}_{3}^{-}\right]=\mathrm{DIC} \frac{\left[\mathrm{H}^{+}\right] K_{1}^{*}}{\left[\mathrm{H}^{+}\right]^{2}+\left[\mathrm{H}^{+}\right] K_{1}^{*}+K_{1}^{*} K_{2}^{*}}} \\
& {\left[\mathrm{CO}_{3}^{2-}\right]=\mathrm{DIC} \frac{K_{1}^{*} K_{2}^{*}}{\left[\mathrm{H}^{+}\right]^{2}+\left[\mathrm{H}^{+}\right] K_{1}^{*}+K_{1}^{*} K_{2}^{*}}}
\end{aligned}
$$

where $K_{v} *=10^{-\mathrm{pK}^{*}}$.

The concentration of $\mathrm{Cl}^{-}$is not observed but can be calculated from electroneutrality:

$$
\begin{aligned}
{\left[\mathrm{Cl}^{-}\right] } & =\left[\mathrm{Na}^{+}\right]+\left[\mathrm{H}^{+}\right]-\left[\mathrm{HCO}_{3}^{-}\right]-2\left[\mathrm{CO}_{3}^{2-}\right]-\left[\mathrm{OH}^{-}\right] \\
& =0.59767 \mathrm{~mol} \mathrm{~kg}{ }^{-1}
\end{aligned}
$$

This simple solution can be prepared in principle by adding $\mathrm{NaCl}$ (0.59767 moles per kilogram solution) and a small amount ( 0.00233 moles per kilogram solution) of $\mathrm{NaHCO}_{3}$ to distilled water, and finally equilibrating with air of $p \mathrm{CO}_{2}=295 \mu \mathrm{atm}\left(\mathrm{pK}_{0}=1.55\right)$. Note that the addition of $\mathrm{NaHCO}_{3}$ is essential to approach conditions similar to those in natural seawater and that our simple system is different from a solution of table salt $(\mathrm{NaCl})$ equilibrated with air.

\subsection{The concept of total alkalinity}

Titration of a sample (say $1 \mathrm{~kg}$ ) of our simple system with $\mathrm{HCl}$ (say $1 \mathrm{~mol} \mathrm{~kg}^{-1}$ ) leads to a decrease of $\mathrm{pH}$ (Fig. 1) whereby most of the $\mathrm{H}^{+}$added is used up to convert $\mathrm{CO}_{3}^{2-}$ to $\mathrm{HCO}_{3}^{-}$and $\mathrm{HCO}_{3}^{-}$to $\mathrm{H}_{2} \mathrm{CO}_{3}$ which dissociates into $\mathrm{CO}_{2}$ and $\mathrm{H}_{2} \mathrm{O}$ (the amount of true carbonic acid, $\mathrm{H}_{2} \mathrm{CO}_{3}$, in aqueous solutions is negligible compared to that of $\mathrm{CO}_{2}$ ). At initial $\mathrm{pH}$ of $8.2, \mathrm{CO}_{3}^{2-}$ and $\mathrm{HCO}_{3}^{-}$are the major proton acceptors in the solution. Total alkalinity can roughly be considered as a measure of the amount of these proton acceptors or more precisely the amount of protons that can be accepted by these acceptors, i.e. $\mathrm{TA} \approx\left[\mathrm{HCO}_{3}^{-}\right]+2\left[\mathrm{CO}_{3}^{2-}\right]$ (the factor 2 stems from the fact that $\mathrm{CO}_{3}^{2-}$ has to accept 2 protons in order to be converted to $\mathrm{CO}_{2}$ ). TA is measured by acidimetric titration which also affects the concentrations of other proton acceptors and proton donors with minor concentrations $\left(\mathrm{OH}^{-}\right.$and $\left.\mathrm{H}^{+}\right)$, thus TA is defined as the excess of proton acceptors over proton donors (see below). At the alkalinity equivalence point (where $\mathrm{TA}=0$, see next section), the $\mathrm{pH}$ is about 4.3 , and thus the TA of the initial sample could be estimated as the amount of $\mathrm{HCl}$ that has to be added to reach this $\mathrm{pH}$.

The explanation given above can be considered as the total alkalinity concept in a nutshell. An exact definition of TA is needed, however, in order to make accurate measurements, especially when complex mixtures of compounds such as natural seawater are concerned. This will now be introduced for the simple system under consideration in this section and later on generalized so that it can be applied to natural water samples. The exact definition of TA requires the introduction of the following concepts: zero level of protons, proton acceptors and donors, proton condition. These concepts will be discussed at some length.

\subsection{Zero level of protons, proton acceptors and donors}

Titration with $\mathrm{HCl}$ results in conversion of $\mathrm{CO}_{3}^{2-}$ to $\mathrm{HCO}_{3}^{-}$and of $\mathrm{HCO}_{3}^{-}$to $\mathrm{CO}_{2}$. The three species $\mathrm{CO}_{2}$, $\mathrm{HCO}_{3}^{-}$, and $\mathrm{CO}_{3}^{2-}$ have different capacities to accept protons in the titration process. $\mathrm{CO}_{2}$ is conventionally chosen as the zero level of protons. $\mathrm{HCO}_{3}^{-}$can accept one proton and thus occupies proton level -1 (with respect to $\mathrm{CO}_{2}$ as the zero level of protons) and $\mathrm{CO}_{3}^{2-}$ can accept two protons and thus occupies proton level -2 (Fig. 2). $\mathrm{HCO}_{3}^{-}$and $\mathrm{CO}_{3}^{2-}$ are called proton acceptors with respect to $\mathrm{CO}_{2}$ as the zero level of protons. The choice of a particular chemical species (here: $\mathrm{CO}_{2}$ ) defines the zero level of protons for a single set of related acid-base species (here: $\mathrm{CO}_{2}, \mathrm{HCO}_{3}^{-}$, and $\mathrm{CO}_{3}^{2-}$ ).

Protons can also be accepted by $\mathrm{OH}^{-}$ions. Thus we must consider the water system as well. The zero level of protons for water is always chosen to be $\mathrm{H}_{2} \mathrm{O}$. Accordingly $\mathrm{OH}^{-}$is a proton acceptor (proton level-1). $\mathrm{H}^{+}\left(\mathrm{H}_{3} \mathrm{O}^{+}\right)$is a proton donor (proton level +1). In fact, a separate zero level of protons must be defined for each acid-base system in a solution. 


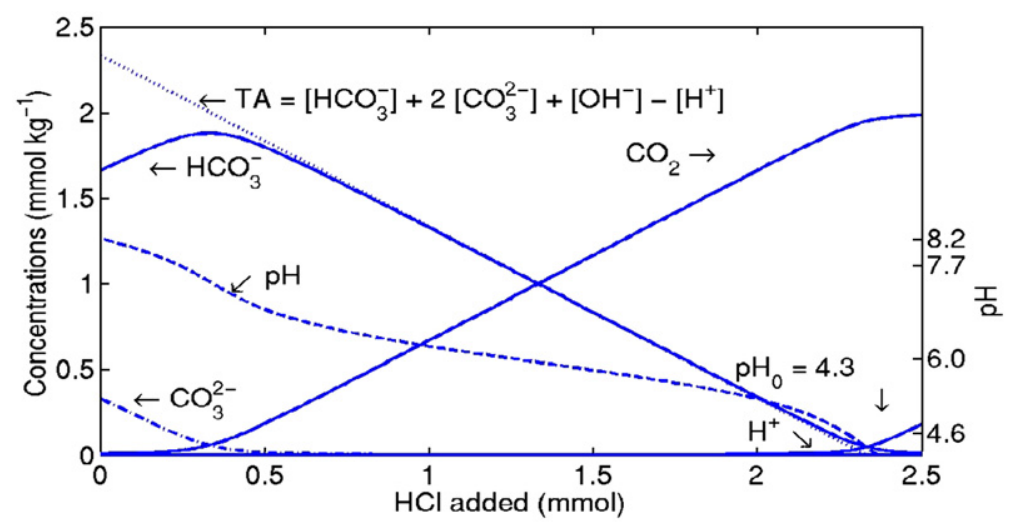

Fig. 1. Variation of the carbonate system species $\left(\mathrm{CO}_{2}, \mathrm{HCO}_{3}^{-}, \mathrm{CO}_{3}^{2-}\right), \mathrm{pH}$, and TA during titration of a $1 \mathrm{~kg}$ sample of the simple system with hydrochloric acid of $1 \mathrm{~mol} \mathrm{~kg}^{-1}$ concentration (Section 2).

\subsection{Definition of alkalinity, proton condition}

The weighted sums of proton acceptors and donors in our simple system at any $\mathrm{pH}$ are given by

proton acceptors $=\left[\mathrm{HCO}_{3}^{-}\right]+2\left[\mathrm{CO}_{3}^{2-}\right]+\left[\mathrm{OH}^{-}\right]$

proton donors $=\left[\mathrm{H}^{+}\right]$

where the weights are given by the magnitude of the proton level defined relative to the chosen zero level of protons for each acid-base system (in case of $\mathrm{CO}_{3}^{2-}$ the proton level is -2 and thus the coefficient is +2 ). At the initial $\mathrm{pH}$ of 8.2 our simple system clearly shows an excess of proton acceptors over donors

proton acceptors $=1660+2 \cdot 331+10$

$=2332 \mu \mathrm{mol} \mathrm{kg}-1$ at $\mathrm{pH}=8.2$

proton donors $=0.0063 \mu \mathrm{mol} \mathrm{kg}-1$ at $\mathrm{pH}=8.2$.

This excess of proton acceptors over donors with respect to the chosen zero level of protons is defined as the total alkalinity (Dickson, 1981):

$$
\begin{aligned}
\mathrm{TA} & =\text { proton acceptors- proton donors } \\
& =\left[\mathrm{HCO}_{3}^{-}\right]+2\left[\mathrm{CO}_{3}^{2-}\right]+\left[\mathrm{OH}^{-}\right]-\left[\mathrm{H}^{+}\right] .
\end{aligned}
$$

For the aqueous solution of our simple system we obtain (all values in $\mu \mathrm{mol} \mathrm{kg}{ }^{-1}$ )

$$
\begin{aligned}
& \mathrm{TA}=1660+2 \cdot 331+10-6.3 \cdot 10^{-3} \\
& \approx 1660+662+10=2332 .
\end{aligned}
$$

The TA of our sample is dominated by the contributions of $\mathrm{HCO}_{3}^{-}$(which is the dominant species of carbonic acid at $\mathrm{pH}=8.2$ ) and $\mathrm{CO}_{3}^{2-}$. The $\mathrm{OH}^{-}$ contributes less than $1 \%$ to TA and $\mathrm{H}^{+}$even less. Seawater samples with $\mathrm{pH}$ around 8.2 show similar features, i.e. TA is dominated by $\mathrm{HCO}_{3}^{-}$and $\mathrm{CO}_{3}^{2-}$ and TA $>$ DIC.

We can now ask: At what point $(\mathrm{pH})$ is $\mathrm{TA}=0$ ? From $\mathrm{TA}=0$ one immediately obtains from Eq. (12)

$$
\left[\mathrm{H}^{+}\right]=\left[\mathrm{HCO}_{3}^{-}\right]+2\left[\mathrm{CO}_{3}^{2-}\right]+\left[\mathrm{OH}^{-}\right]
$$

which is a so-called proton condition. It defines the $\mathrm{pH}$ at which proton donors (left-hand side of Eq. (15)) exactly balance the proton acceptors (right-hand side of Eq. (15)). $\left[\mathrm{H}^{+}\right]$can be calculated as the unique positive solution of the fourth order equation

$$
\left[\mathrm{H}^{+}\right]=\mathrm{DIC} \frac{\left[\mathrm{H}^{+}\right] K_{1}^{*}+2 K_{1}^{*} K_{2}^{*}}{\left[\mathrm{H}^{+}\right]^{2}+\left[\mathrm{H}^{+}\right] K_{1}^{*}+K_{1}^{*} K_{2}^{*}}+\frac{K_{\mathrm{W}}^{*}}{\left[\mathrm{H}^{+}\right]} .
$$

The corresponding $\mathrm{pH}$, denoted by $\mathrm{pH}_{0}$, is called the $\mathrm{CO}_{2}$-equivalence point $\left(\mathrm{CO}_{2}\right.$ : because it is the zero level of protons). It defines the point at which $\mathrm{TA}=0$. For the aqueous solution of our simple system one obtains $\mathrm{pH}_{0} \approx 4.3$.

\subsection{Discussion}

In order to reach the summit of TA definition we followed a safe route along a mountain ridge. In this subsection we will explore some of the abysses we passed by.

\subsubsection{Dilution factor}

Addition of $\mathrm{HCl}$ (typically $0.1 \mathrm{~mol} \mathrm{~kg}^{-1}$ ) during titration leads to a slight decrease of the concentration of conservative ions. For addition of $\mathrm{HCl}$ with a concentration of $0.1 \mathrm{~mol} \mathrm{~kg}^{-1}$ to a solution with a TA of 


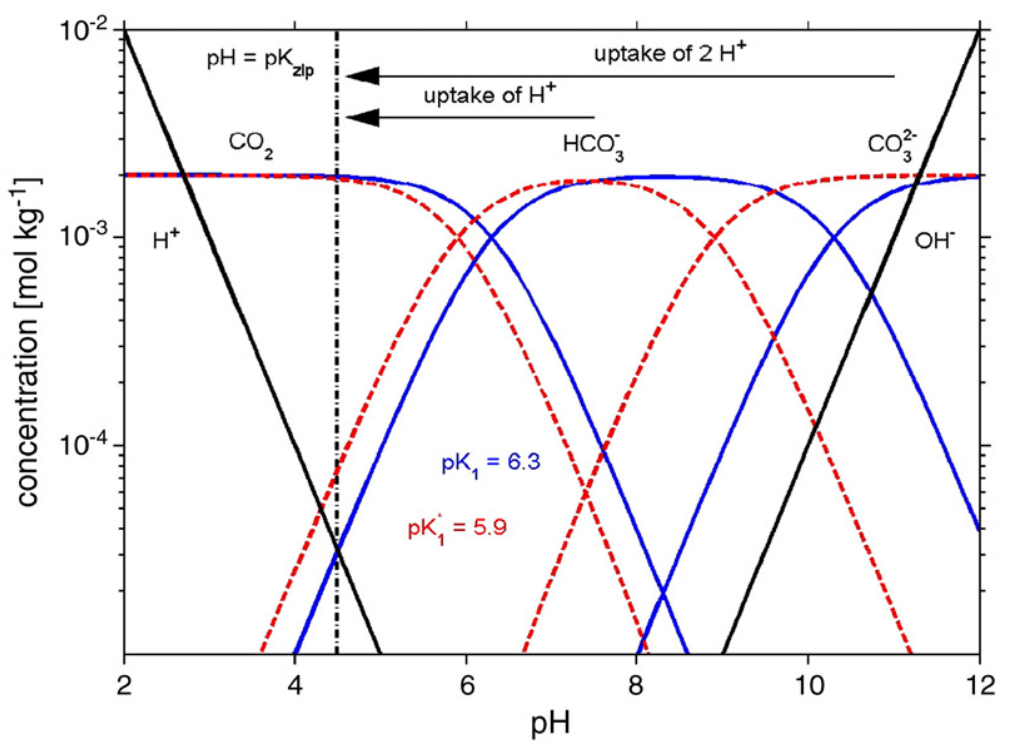

Fig. 2. Concentrations of $\mathrm{CO}_{2}, \mathrm{HCO}_{3}^{-}, \mathrm{CO}_{3}^{2-}, \mathrm{H}^{+}$, and $\mathrm{OH}^{-}$as functions of $\mathrm{pH}$ (Bjerrum plot) calculated using thermodynamic $\mathrm{pK}$ values for zero ionic strength (blue solid lines) or stoichiometric $\mathrm{pK}$ values $\left(\mathrm{pK}^{*}\right)$ typical for seawater and used here for the simple system (red dashed lines). $\mathrm{CO}_{2}$ dominates for $\mathrm{pH}$ below $\mathrm{pK}_{1}, \mathrm{CO}_{3}^{2-}$ above $\mathrm{pK}_{2}$, and $\mathrm{HCO}_{3}^{-}$in between. The lines of $\left[\mathrm{H}^{+}\right]$and $\left[\mathrm{HCO}_{3}^{-}\right]$cross at $\mathrm{pH} \approx 4.5$ (fresh water $\mathrm{pK}$ 's) and $\mathrm{pH} \approx 4.3(\mathrm{seawater}$ pK's). (For interpretation of the references to colour in this figure legend, the reader is referred to the web version of this article.)

$2500 \mu \mathrm{mol} \mathrm{kg}^{-1}$ or less, the maximum dilution factor is $2.5 \%$. This small dilution effect has been neglected in all our calculations because it is not essential for the explanation of the TA concept; it has to be considered, however, for accurate measurements. The dilution effect can be taken into account by using the linear mixing relation (Eq. (1); for details compare Dickson, 1981).

\subsubsection{Proton condition}

Note that the concentrations in the proton condition (Eq. (15)) are not the initial concentrations of our sample. Instead the proton condition defines a $\mathrm{pH}$ (the $\mathrm{CO}_{2}$-equivalence point). To make this clearer an index (0) could be added to all concentrations:

$$
\left[\mathrm{H}^{+}\right]_{0}=\left[\mathrm{HCO}_{3}^{-}\right]_{0}+2\left[\mathrm{CO}_{3}^{2-}\right]_{0}+\left[\mathrm{OH}^{-}\right]_{0} .
$$

\subsubsection{Different choices of zero level of protons yield different proton conditions}

Other proton conditions can be defined for carbonic acid by the choice of different zero levels of protons. If, for example, $\mathrm{HCO}_{3}^{-}$is chosen as the zero level of protons for $\mathrm{CO}_{2}$ species the corresponding proton condition reads

$$
\left[\mathrm{H}^{+}\right]+\left[\mathrm{CO}_{2}\right]=\left[\mathrm{CO}_{3}^{2-}\right]+\left[\mathrm{OH}^{-}\right]
$$

where $\mathrm{CO}_{2}$ is now a proton donor with $\mathrm{HCO}_{3}^{-}$as zero level of protons and $\mathrm{CO}_{3}^{2-}$ is just one proton below the zero level of protons and thus $\left[\mathrm{CO}_{3}^{2-}\right]$ is not multiplied by 2 here. The $\mathrm{pH}_{0}(\approx 7.4$ for our simple system $)$ resulting from this proton condition is the $\mathrm{HCO}_{3}^{-}$equivalence point. It was our choice, however, to select $\mathrm{CO}_{2}$ as zero level of protons to define total alkalinity.

\subsubsection{Defining the zero level of protons by a $p K$ value}

The zero level of protons is defined by choosing a certain chemical species (for example, $\mathrm{CO}_{2}$ ). Chemical species above or below this zero level of protons (for example, $\mathrm{HCO}_{3}^{-}, \mathrm{CO}_{3}^{2-}$ ) have to donate or accept protons when they are converted to the species defined as the zero level of protons and are thus called proton donors and acceptors, respectively. The definition of the zero level of protons is thus specific to each particular acid-base system, and does not lend itself to a generalization to other acidbase systems. A relation between proton donors, acceptors, and the choice of the species that define the zero level of protons can be obtained, however, by specifying a single $\mathrm{pK}$ value, $\mathrm{pK}_{\mathrm{zlp}}$, which applies for all acid-base systems as a dividing point in the following sense. The chemical species which dominates (largest concentration compared to the other chemical species of the same acid-base system) at $\mathrm{pH}=\mathrm{pK}_{\text {zlp }}$ defines the zero level of protons, acids with $\mathrm{pK} \leq \mathrm{pK}_{\mathrm{zlp}}$ are proton donors (acids!), and bases formed from weak acids with $\mathrm{pK}>\mathrm{pK}_{\mathrm{zlp}}$ are proton acceptors.

\subsubsection{Selection of a value for $p K_{z l p}$. $p K$ or $p K^{*}$ ?}

To make the definition of the zero level of protons independent of temperature, pressure or composition of 
the natural water sample, Dickson (1981) proposed using thermodynamic $\mathrm{pK}$ values at $25^{\circ} \mathrm{C}$, standard pressure (1 atm), and zero ionic strength. The choice of $\mathrm{pK}_{\mathrm{zlp}}=4.5$ by Dickson (1981) is a convention (the motivation for this specific choice is given below). In the case of the carbonic acid system with $\mathrm{pK}_{1}=6.3$ and $\mathrm{pK}_{2}=10.3$ this choice leads to $\mathrm{CO}_{2}$ as the zero level of proton species (because it dominates at $\mathrm{pH}=\mathrm{pK}_{\mathrm{zlp}}=4.5$ ), $\mathrm{HCO}_{3}^{-}$and $\mathrm{CO}_{3}^{2-}$ are bases (proton acceptors) with $\mathrm{pK}$ values above $\mathrm{pK}_{\mathrm{zlp}}=4.5$. For the water system $\left(\mathrm{H}_{2} \mathrm{O}\right.$, $\left.\mathrm{H}^{+}, \mathrm{OH}^{-}\right) \mathrm{H}_{2} \mathrm{O}$ is always the dominant species and is thus the zero level of protons.

For our simple system the exact value of $\mathrm{pK}_{\text {zlp }}$ does not matter as long as it is below $\mathrm{pK}_{1}$ because it would lead to the same division into zero level of proton species, proton donors, and proton acceptors for the carbonic acid system. In natural water samples, however, several other acid-base systems contribute to TA. Dickson (1981) chose $\mathrm{pK}_{\mathrm{zlp}}$ such that it is below $\mathrm{pK}_{1}$ and so that systems that are of no interest do not contribute to TA (this was achieved by choosing $\mathrm{pK}_{\mathrm{zlp}}$ above those of hydrogen sulphate $(\mathrm{pK}=2)$ and hydrogen fluoride $\left(\mathrm{pK}_{\mathrm{HF}}=3.2\right)$ ), i.e. $\mathrm{pK}_{\mathrm{HF}}=3.2<$ $\mathrm{pK}_{\mathrm{zlp}}<\mathrm{pK}_{1}=6.3 . \mathrm{pK}_{\mathrm{zlp}}=4.5$ was chosen to correspond roughly to the $\mathrm{pH}$ of the conventional alkalinity end-point, and is nearly in the middle of this range. Stoichiometric constants $\left(\mathrm{pK}^{*}\right)$ for $\mathrm{CO}_{2}$ species of natural water sample are different from the thermodynamic constants at $25^{\circ} \mathrm{C}$, standard pressure (1 atm), and zero ionic strength (for example, $\mathrm{pK}_{1}^{*} \approx 5.9$ in seawater at $25^{\circ} \mathrm{C}$, standard pressure, $S=35$ versus $\mathrm{pK}_{1}=6.3$; Fig. 2 ) but they never come close to 4.5 in natural waters and thus a classification into proton donors and acceptors using stoichiometric values would lead to the same results for the typical inorganic contributors to TA, but might result in differences for minor organic acid-base systems.

\subsubsection{Explicit conservative expression for total alkalinity}

None of the chemical species in the TA definition (Eq. (12)) is conservative, i.e. their concentrations (measured in gravimetric units) change with pressure and temperature. One can combine the TA expression (Eq. (12)) with the electroneutrality relation (Eq. (6)) to derive an alternative expression for TA. In our simple system

$$
\begin{aligned}
\mathrm{TA}_{\mathrm{ec}} & =\left[\mathrm{Na}^{+}\right]-\left[\mathrm{Cl}^{-}\right] \equiv \mathrm{TA} \\
& =\left[\mathrm{HCO}_{3}^{-}\right]+2\left[\mathrm{CO}_{3}^{2-}\right]+\left[\mathrm{OH}^{-}\right]-\left[\mathrm{H}^{+}\right]
\end{aligned}
$$

The expression for $\mathrm{TA}_{\mathrm{ec}}$ contains concentrations of conservative ions only and is thus called the explicit conservative expression of total alkalinity. It is distinct from but equivalent to TA. Later on, an analogous explicitly conservative expression will be derived for
Dickson's TA definition. It will be shown that this explicit conservative expression of total alkalinity is extremely useful for the calculation of changes of TA due to certain biogeochemical processes (Section 5).

\section{Including other acid-base systems}

Natural water samples contain various acid-base systems (Fig. 3) that can accept and donate protons (Table 1). The recipe for including these acid-base systems in the expression for total alkalinity is quite simple: the choice of $\mathrm{pK}_{\mathrm{zlp}}=4.5$ defines a level of zero protons and implies a classification of chemical species into proton acceptors and proton donors as well as the species that is neutral for TA (the zero level of protons) for each acid-base system (Table 1). TA is defined, as before, by the excess of proton acceptors over proton donors with respect to the various species that each define their respective zero level of protons. In the following we will derive the zero level of protons species, the proton acceptors, the proton donors, and the proton condition for each acid-base system separately, as though it were the only acid base system in the solution of interest, and discuss some of their peculiarities. The thermodynamic pK values used here stem from Dickson (1981).

\subsection{Boric acid}

$\mathrm{B}(\mathrm{OH})_{3}+\mathrm{H}_{2} \mathrm{O} \rightleftharpoons \mathrm{B}(\mathrm{OH})_{4}^{-}+\mathrm{H}^{+}, \quad \mathrm{pK}=9.2$. At $\mathrm{pH}=\mathrm{pK}_{\mathrm{zlp}}=4.5, \mathrm{~B}(\mathrm{OH})_{3}$ is the dominant species, i.e. the zero level of protons. $\mathrm{B}(\mathrm{OH})_{4}^{-}$with $\mathrm{pK}=9.2>\mathrm{pK}_{\mathrm{zlp}}=4.5$ is a proton acceptor. Thus the corresponding proton condition is

$\left[\mathrm{H}^{+}\right]=\left[\mathrm{B}(\mathrm{OH})_{4}^{-}\right]+\left[\mathrm{OH}^{-}\right]$.

\subsection{Phosphoric acid (or phosphate)}

$\mathrm{H}_{3} \mathrm{PO}_{4}$ can dissociate into $\mathrm{H}_{2} \mathrm{PO}_{4}^{-}, \mathrm{HPO}_{4}^{2-}$, and $\mathrm{PO}_{4}^{3-}$ with $\mathrm{pK}_{1}=2.1, \mathrm{pK}_{2}=7.2$, and $\mathrm{pK}_{3}=12.7$. At $\mathrm{pH}=$ $\mathrm{pK}_{\mathrm{zlp}}=4.5, \mathrm{H}_{2} \mathrm{PO}_{4}^{-}$is the dominant species, i.e. the zero level of protons. $\mathrm{HPO}_{4}^{2-}$ with $\mathrm{pK}_{2}=7.2$ and $\mathrm{PO}_{4}^{3-}$ with $\mathrm{pK}_{3}=12.7$ are proton acceptors whereas $\mathrm{H}_{3} \mathrm{PO}_{4}$ with $\mathrm{pK}_{1}=2.1<\mathrm{pK}_{\mathrm{zlp}}=4.5$ is a proton donor. The corresponding proton condition is

$\left[\mathrm{H}^{+}\right]+\left[\mathrm{H}_{3} \mathrm{PO}_{4}\right]=\left[\mathrm{HPO}_{4}^{2-}\right]+2\left[\mathrm{PO}_{4}^{3-}\right]+\left[\mathrm{OH}^{-}\right]$.

Several features are noteworthy compared to the proton condition for carbonic acid (Eq. (15)). This proton condition for phosphate contains a neutral species $\left(\mathrm{H}_{3} \mathrm{PO}_{4}\right)$ which clearly shows that proton conditions 

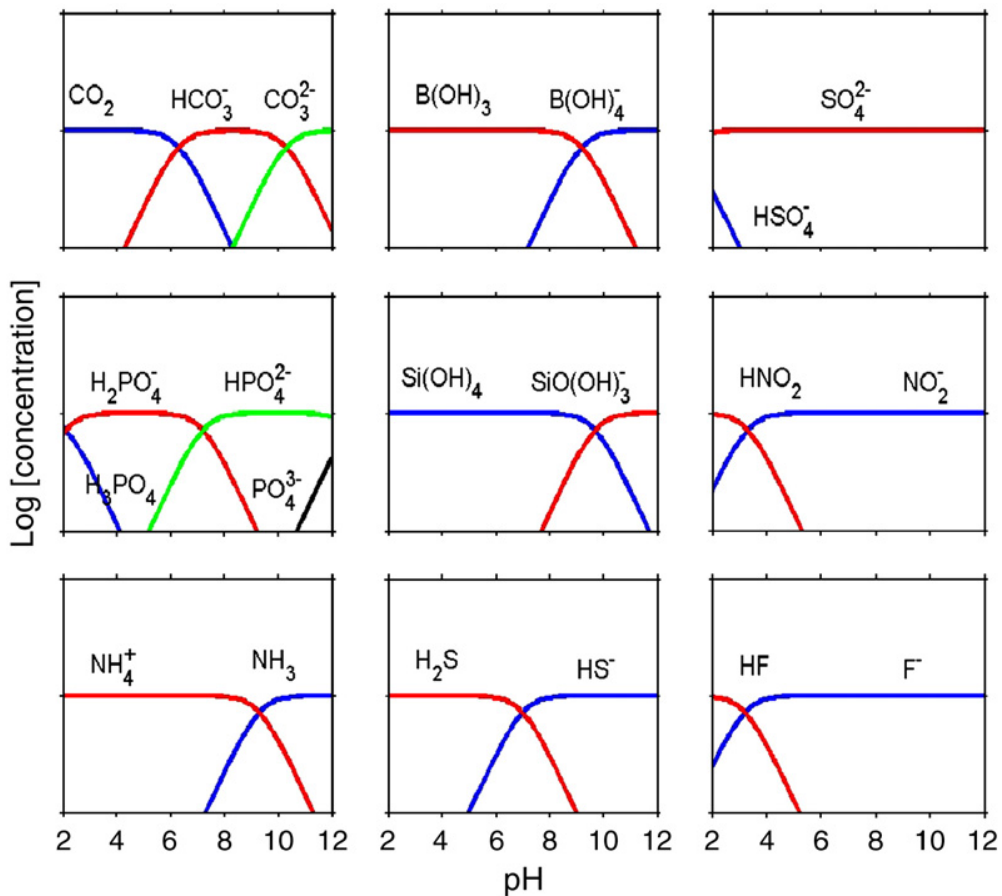

Fig. 3. Bjerrum plots for various acid-base systems. The thermodynamic pK values used here stem from Dickson (1981).

are not simple charge balances between ions. As a consequence, the expression for TA can contain not only ions but also neutral species. Please note also that the coefficients of $\mathrm{HPO}_{4}^{2-}$ (1) and $\mathrm{PO}_{4}^{3-}$ (2) are different from -1 times their charges; they are given by the difference in number of protons from $\mathrm{H}_{2} \mathrm{PO}_{4}^{-}$ which is the zero level of protons (compare Zeebe and Wolf-Gladrow, 2001, Chapter 1.2 .3 for a more detailed discussion).

\subsection{Hydrogen sulphate}

$\mathrm{HSO}_{4}^{-} \rightleftharpoons \mathrm{SO}_{4}^{2-}+\mathrm{H}^{+}$with $\mathrm{pK}=2.0$. At $\mathrm{pH}=\mathrm{pK}_{\mathrm{zlp}}=$ $4.5, \mathrm{SO}_{4}^{2-}$ is the dominant species, i.e. the zero level of protons. $\mathrm{HSO}_{4}^{-}$with $\mathrm{pK}=2.0<\mathrm{pK}_{\mathrm{zlp}}=4.5$ is a proton donor. The proton condition is

$\left[\mathrm{H}^{+}\right]+\left[\mathrm{HSO}_{4}^{-}\right]=\left[\mathrm{OH}^{-}\right]$.

Please note that $\mathrm{H}_{2} \mathrm{SO}_{4}$ has not been included as a proton donor here because its concentration is tiny (vanishing for all practical purposes; due to its low $\mathrm{pK}<$ -3 ) over the $\mathrm{pH}$ range of titration (which may go down to 3.0, Watanabe et al., 2004).

\subsection{Hydrofluoric acid}

$\mathrm{HF} \rightleftharpoons \mathrm{F}^{-}+\mathrm{H}^{+}$with $\mathrm{pK}=3.2$. At $\mathrm{pH}=\mathrm{pK}_{\mathrm{zlp}}=4.5, \mathrm{~F}^{-}$ is the dominant species, i.e. the zero level of protons. $\mathrm{HF}$ with $\mathrm{pK}=3.2<\mathrm{pK}_{\mathrm{zlp}}=4.5$ is a proton donor. Thus the corresponding proton condition is

$\left[\mathrm{H}^{+}\right]+[\mathrm{HF}]=\left[\mathrm{OH}^{-}\right]$.

\subsection{Silicic acid}

$\mathrm{H}_{4} \mathrm{SiO}_{4}$ can dissociate into $\mathrm{H}_{3} \mathrm{SiO}^{-}$with $\mathrm{pK}_{1}=9.7$. Species of higher degree of dissociation are not included here because their concentrations in natural water samples are tiny (vanishing for all practical purposes). At $\mathrm{pH}=\mathrm{pK}_{\mathrm{zlp}}=4.5, \mathrm{H}_{4} \mathrm{SiO}_{4}$ is the dominant species, i.e. the zero level of protons. $\mathrm{H}_{3} \mathrm{SiO}_{4}^{-}$with $\mathrm{pK}=9.7>\mathrm{pK}_{\mathrm{zlp}}=4.5$ is a proton acceptor. The corresponding proton condition is

$\left[\mathrm{H}^{+}\right]=\left[\mathrm{H}_{3} \mathrm{SiO}_{4}^{-}\right]+\left[\mathrm{OH}^{-}\right]$.

\subsection{Hydrogen sulfide}

$\mathrm{H}_{2} \mathrm{~S}$ can dissociate into $\mathrm{HS}^{-}$with $\mathrm{pK}_{1}=7.0 . \mathrm{S}^{2-}$ is not included here because its concentration in aqueous solutions is essentially zero due to its high $\mathrm{pK}$. At $\mathrm{pH}=\mathrm{pK}_{\mathrm{zlp}}=4.5, \mathrm{H}_{2} \mathrm{~S}$ is the dominant species, i.e. the zero level of protons. $\mathrm{HS}^{-}$with $\mathrm{pK}=7.0>\mathrm{pK}_{\mathrm{zlp}}=4.5$ is a proton acceptor. The corresponding proton condition is

$$
\left[\mathrm{H}^{+}\right]=\left[\mathrm{HS}^{-}\right]+\left[\mathrm{OH}^{-}\right] .
$$


Table 1

Acid-base systems: proton acceptors and donors

\begin{tabular}{|c|c|c|c|c|}
\hline Acid & $\mathrm{pK}_{1}, \mathrm{pK}_{2}, \ldots$ & Zero level of proton species & Proton acceptors & Proton donors \\
\hline $\mathrm{H}_{2} \mathrm{CO}_{3}$ & $6.3,10.3$ & $\mathrm{CO}_{2}$ & $\mathrm{HCO}_{3}^{-}, \mathrm{CO}_{3}^{2-}$ & \\
\hline $\mathrm{B}(\mathrm{OH})_{3}$ & 9.2 & $\mathrm{~B}(\mathrm{OH})_{3}$ & $\mathrm{~B}(\mathrm{OH})_{4}^{-}$ & \\
\hline $\mathrm{H}_{3} \mathrm{PO}_{4}$ & $2.1,7.2,12.7$ & $\mathrm{H}_{2} \mathrm{PO}_{4}^{-}$ & $\mathrm{HPO}_{4}^{2-}, \mathrm{PO}_{4}^{3-}$ & $\mathrm{H}_{3} \mathrm{PO}_{4}$ \\
\hline $\mathrm{HSO}_{4}^{-}$ & 2.0 & $\mathrm{SO}_{4}^{2-}$ & & $\mathrm{HSO}_{4}^{-}$ \\
\hline $\mathrm{HF}$ & 3.2 & $\mathrm{~F}^{-}$ & & $\mathrm{HF}$ \\
\hline $\mathrm{H}_{4} \mathrm{SiO}_{4}$ & 9.7 & $\mathrm{H}_{4} \mathrm{SiO}_{4}$ & $\mathrm{H}_{3} \mathrm{SiO}_{4}^{-}$ & \\
\hline $\mathrm{H}_{2} \mathrm{~S}$ & 7.0 & $\mathrm{H}_{2} \mathrm{~S}$ & $\mathrm{HS}^{-}$ & \\
\hline $\mathrm{NH}_{3}$ & 9.3 & $\mathrm{NH}_{4}^{+}$ & $\mathrm{NH}_{3}$ & \\
\hline $\mathrm{HNO}_{2}$ & 3.3 & $\mathrm{NO}_{2}^{-}$ & & \\
\hline
\end{tabular}

$\mathrm{HNO}_{2}$ is not listed in Dickson's expression for TA because of its tiny concentration in seawater.

\subsection{Ammonia}

$\mathrm{NH}_{4}^{+} \rightleftharpoons \mathrm{NH}_{3}+\mathrm{H}^{+}$with $\mathrm{pK}=9.3$. At $\mathrm{pH}=\mathrm{pK}_{\mathrm{zlp}}=4.5$, $\mathrm{NH}_{4}^{+}$is the dominant species, i.e. the zero level of protons. $\mathrm{NH}_{3}$ with $\mathrm{pK}=9.3>\mathrm{pK}_{\mathrm{zlp}}=4.5$ is a proton acceptor. The corresponding proton condition is

$\left[\mathrm{H}^{+}\right]=\left[\mathrm{NH}_{3}\right]+\left[\mathrm{OH}^{-}\right]$.

\subsection{Nitrous acid}

$\mathrm{HNO}_{2} \rightleftharpoons \mathrm{NO}_{2}^{-}+\mathrm{H}^{+}$with $\mathrm{pK}=3.3$. At $\mathrm{pH}=\mathrm{pK}_{\mathrm{zlp}}=4.5$, $\mathrm{NO}_{2}^{-}$is the dominant species, i.e. the zero level of protons. $\mathrm{HNO}_{2}$ with $\mathrm{pK}=3.3<\mathrm{pK}_{\mathrm{zlp}}=4.5$ is a proton donor. Thus the corresponding proton condition is

$\left[\mathrm{H}^{+}\right]+\left[\mathrm{HNO}_{2}\right]=\left[\mathrm{OH}^{-}\right]$.

Please note that each separate proton condition defines a distinct equivalence point $\left(\mathrm{pH}_{0}\right)$ which is a function of the $\mathrm{pK}$ values of the acid-base system, the ion product of water, and the total concentration of all species of the acid.

\subsection{Nitrate}

The major nutrient nitrate $\left(\mathrm{HNO}_{3} \rightleftharpoons \mathrm{NO}_{3}^{-}+\mathrm{H}^{+}\right.$with a $\mathrm{pK}=-1$ ) does not show up in the alkalinity expression (Eq. (28)); because it is the anion of a strong acid no protons are accepted or donated over the titration range. This does not mean, however, that assimilation of nitrate by algae has no effect on TA (see discussion in Section 5).

\subsection{Other proton acceptors}

Kim et al. (2006) have shown that negatively charged surface groups on phytoplankton and bacterial cells react with protons during titration with hydrochloric acid. As a consequence there can be a difference in measured total alkalinity between filtered and unfiltered water. Acid-base functional groups in the dissolved organic carbon pool in seawater can also have a small influence on TA as well.

\subsection{Dickson's expression for total alkalinity in natural water samples}

Total alkalinity is defined by the excess of proton acceptors over proton donors with respect to the proton condition defined by the value 4.5 for $\mathrm{pK}_{\mathrm{zlp}}$ (Dickson, 1981) which leads to the expression

$$
\begin{aligned}
\mathrm{TA}= & {\left[\mathrm{HCO}_{3}^{-}\right]+2\left[\mathrm{CO}_{3}^{2-}\right]+\left[\mathrm{B}(\mathrm{OH})_{4}^{-}\right]+\left[\mathrm{OH}^{-}\right] } \\
& +\left[\mathrm{HPO}_{4}^{2-}\right]+2\left[\mathrm{PO}_{4}^{3-}\right]+\left[\mathrm{H}_{3} \mathrm{SiO}_{4}^{-}\right]+\left[\mathrm{NH}_{3}\right] \\
& +\left[\mathrm{HS}^{-}\right]+\ldots-\left[\mathrm{H}^{+}\right]-\left[\mathrm{HSO}_{4}^{-}\right]-[\mathrm{HF}]-\left[\mathrm{H}_{3} \mathrm{PO}_{4}\right] \\
& -\left[\mathrm{HNO}_{2}\right]+\ldots
\end{aligned}
$$

where the ellipses stand for additional, as yet unidentified, acid-base species (Dickson, 1981, 1992; DOE, 1994; we have added $-\left[\mathrm{HNO}_{2}\right]$ to Dickson's original expression). $\mathrm{TA}=0$ is reached at the $\mathrm{pH}$ that is defined by the proton condition (balance of proton donors and acceptors)

$$
\begin{aligned}
{\left[\mathrm{H}^{+}\right]+} & {\left[\mathrm{HSO}_{4}^{-}\right]+[\mathrm{HF}]+\left[\mathrm{H}_{3} \mathrm{PO}_{4}\right]+\left[\mathrm{HNO}_{2}\right] \ldots } \\
& =\left[\mathrm{HCO}_{3}^{-}\right]+2\left[\mathrm{CO}_{3}^{2-}\right]+\left[\mathrm{B}(\mathrm{OH})_{4}^{-}\right]+\left[\mathrm{OH}^{-}\right] \\
& +\left[\mathrm{HPO}_{4}^{2-}\right]+2\left[\mathrm{PO}_{4}^{3-}\right]+\left[\mathrm{H}_{3} \mathrm{SiO}_{4}^{-}\right]+\left[\mathrm{NH}_{3}\right] \\
& +\left[\mathrm{HS}^{-}\right] \ldots
\end{aligned}
$$

\section{The explicit conservative expression for total alkalinity}

Macroscopic volumes (size larger than the Debye length $\approx 0.4 \mathrm{~nm}$ in seawater) of aqueous solutions obey electroneutrality, i.e. the sum of all charges is zero:

$\sum_{i} q_{i}\left[c_{i}\right]=0$ 
where $\left[c_{i}\right]$ is the concentration (in gravimetric units) and $q_{i}$ the electric charge (in elementary units), respectively, of the species $c_{i}$ and the summation runs over all species. An explicit expression that contains the most important (in terms of concentration) ions in oxic seawater reads

$$
\begin{aligned}
& {\left[\mathrm{Na}^{+}\right]+2\left[\mathrm{Mg}^{2+}\right]+2\left[\mathrm{Ca}^{2+}\right]+\left[\mathrm{K}^{+}\right]+2\left[\mathrm{Sr}^{2+}\right]} \\
& \quad+\ldots+\left[\mathrm{NH}_{4}^{+}\right]+\left[\mathrm{H}^{+}\right]+\ldots-\left[\mathrm{Cl}^{-}\right]-2\left[\mathrm{SO}_{4}^{2-}\right]-\left[\mathrm{Br}^{-}\right] \\
& \quad-\left[\mathrm{NO}_{3}^{-}\right]-\left[\mathrm{NO}_{2}^{-}\right]-\ldots-\left[\mathrm{HCO}_{3}^{-}\right]-2\left[\mathrm{CO}_{3}^{2-}\right]-\left[\mathrm{B}(\mathrm{OH})_{4}^{-}\right] \\
& \quad-\left[\mathrm{OH}^{-}\right]-\left[\mathrm{HS}^{-}\right]-\left[\mathrm{H}_{3} \mathrm{SiO}_{4}^{-}\right]-\left[\mathrm{HSO}_{4}^{-}\right]-\left[\mathrm{F}^{-}\right]-\left[\mathrm{H}_{2} \mathrm{PO}_{4}^{-}\right] \\
& \quad-2\left[\mathrm{HPO}_{4}^{2-}\right]-3\left[\mathrm{PO}_{4}^{3-}\right]=0
\end{aligned}
$$

where the ellipses stand for additional ions (with minor or even negligible concentrations).

If terms are added to both sides of Eq. (31) until Dickson's expression for total alkalinity (Eq. (28)) appears on the right-hand side of the equation, the lefthand side then reads:

$$
\begin{aligned}
& {\left[\mathrm{Na}^{+}\right]+2\left[\mathrm{Mg}^{2+}\right]+2\left[\mathrm{Ca}^{2+}\right]+\left[\mathrm{K}^{+}\right]+2\left[\mathrm{Sr}^{2+}\right]} \\
& \quad+\ldots-\left[\mathrm{Cl}^{-}\right]-\left[\mathrm{Br}^{-}\right]-\left[\mathrm{NO}_{3}^{-}\right]-\ldots \mathrm{TPO}_{4} \\
& \quad+\mathrm{TNH}_{3}-2 \mathrm{TSO}_{4}-\mathrm{THF}-\mathrm{THNO}_{2} \\
& \quad=\mathrm{TA}_{\mathrm{ec}}
\end{aligned}
$$

where $\mathrm{TPO}_{4}=\left[\mathrm{H}_{3} \mathrm{PO}_{4}\right]+\left[\mathrm{H}_{2} \mathrm{PO}_{4}^{-}\right]+\left[\mathrm{HPO}_{4}^{2-}\right]+\left[\mathrm{PO}_{4}^{3-}\right]$, $\mathrm{TNH}_{3}=\left[\mathrm{NH}_{3}\right]+\left[\mathrm{NH}_{4}^{+}\right], \mathrm{TSO}_{4}=\left[\mathrm{SO}_{4}^{2-}\right]+\left[\mathrm{HSO}_{4}^{-}\right], \mathrm{THF}=$ $\left[\mathrm{F}^{-}\right]+[\mathrm{HF}]$, and $\mathrm{THNO}_{2}=\left[\mathrm{NO}_{2}^{-}\right]+\left[\mathrm{HNO}_{2}\right]$ are total phosphate, ammonia, sulphate, fluoride, and nitrite, respectively (the contribution of $\mathrm{H}_{2} \mathrm{SO}_{4}$ to total sulphate can be neglected). Please note that even when the concentrations of various phosphate species change with pressure or temperature, total phosphate concentration stays constant and obeys the linear mixing relation. Thus, following our definition, total phosphate is a conserved quantity and the same applies to the other total concentrations. We denote expression (32) as the explicitly conservative form of total alkalinity or $\mathrm{TA}_{\mathrm{ec}}$ because each single term in this expression is conservative. $\mathrm{TA}_{\mathrm{ec}}$ is not a new definition of total alkalinity. $\mathrm{TA}_{\mathrm{ec}}$ is a different expression for total alkalinity that is equivalent to Dickson's expression (Eq. (28)). In the next section it will be shown that changes of total alkalinity due to biogeochemical processes can be calculated easily using $\mathrm{TA}_{\mathrm{ec}}$.

\section{Changes of alkalinity due to biogeochemical processes}

In the oceans total alkalinity changes first of all with salinity (compare, for example, Friis et al., 2003) as do the concentrations of $\mathrm{Na}^{+}, \mathrm{Cl}^{-}$etc. Further important changes are due to various biogeochemical processes such as calcium carbonate precipitation or production of particulate organic matter by microalgae. It is often difficult to derive the exact amount of these changes from the standard definition of alkalinity in terms of the non-conserved species (Eq. (28)) because an addition or uptake of $\mathrm{CO}_{2}$ or phosphate, for example, affects also the $\mathrm{pH}$ and therefore the concentration of all other species listed in Eq. (28). In the literature, one can read: "Estimating from the dissociation constants of acid in sea water..., addition of 1 mole of phosphoric acid causes a decrease in titration alkalinity which is very close to 1 equivalent." It can be shown, however, that based on Eq. (32) the decrease in total alkalinity is exactly 1 mole per mole phosphoric acid. $\mathrm{TPO}_{4}$ enters Eq. (32) with a negative sign. Thus increasing $\mathrm{TPO}_{4}$ by 1 mole reduces TA by precisely the same amount. In contrast, the addition of 1 mole of $\mathrm{Na}_{3} \mathrm{PO}_{4}$ would lead to an increase of TA by 2 moles per mole $\mathrm{Na}_{3} \mathrm{PO}_{4}:\left[\mathrm{Na}^{+}\right]$ increases by 3 moles and $\mathrm{TPO}_{4}$ by 1 mole per mole $\mathrm{Na}_{3} \mathrm{PO}_{4}$ added, the difference is 2 moles per mole $\mathrm{Na}_{3} \mathrm{PO}_{4}$.

Total alkalinity does not change as a result of invasion of $\mathrm{CO}_{2}$ from or release to the atmosphere. This might be difficult to recognize from Dickson's expression for TA because invasion of $\mathrm{CO}_{2}$ will decrease $\mathrm{pH}$ ('acidification of the ocean'). Thus all concentrations in his expression will change and it is not obvious that the sum stays constant. Invasion or release of $\mathrm{CO}_{2}$ does not affect any concentration in $\mathrm{TA}_{\mathrm{ec}}$ (Eq. (32)) and thus it is evident that total alkalinity stays constant.

\subsection{Calcium carbonate precipitation and dissolution}

The precipitation of $\mathrm{CaCO}_{3}$ can be described by

$\mathrm{Ca}^{2+}+2 \mathrm{HCO}_{3}^{-} \Rightarrow \mathrm{CaCO}_{3}+\mathrm{CO}_{2}+\mathrm{H}_{2} \mathrm{O}$

or by

$\mathrm{Ca}^{2+}+\mathrm{CO}_{3}^{2-} \Rightarrow \mathrm{CaCO}_{3}$.

These summary reactions obey conservation of charge and of all elements involved. However, they should not be interpreted as if $\left[\mathrm{CO}_{2}\right]$ increases when $\mathrm{HCO}_{3}^{-}$is the carbon source for $\mathrm{CaCO}_{3}$ whereas no $\mathrm{CO}_{2}$ is released when $\mathrm{CO}_{3}^{2-}$ is used. In a closed system the precipitation of 1 mole $\mathrm{CaCO}_{3}$ always leads to a decrease of 1 mole in DIC and 2 moles in TA (Eq. (32)). The changes of $\left[\mathrm{CO}_{2}\right]$ (increase, but much less than 1 mole per mole $\mathrm{CaCO}_{3}$ precipitated), 
$\left[\mathrm{HCO}_{3}^{-}\right]$and $\left[\mathrm{CO}_{3}^{2-}\right]$ (decrease) can be calculated from DIC and TA (Fig. 4a-c). In an open system, such as the upper ocean mixed layer, the increase of $\left[\mathrm{CO}_{2}\right]$ leads to outgassing and therefore to a further decrease of DIC (Fig. 4d). One should also note that the carbon source for calcification cannot be inferred from observed changes in DIC and TA. Dissolution of $\mathrm{CaCO}_{3}$ has the reverse effect, i.e. DIC increases by 1 and TA by 2 moles per mole $\mathrm{CaCO}_{3}$. From our $\mathrm{TA}_{\mathrm{ec}}$ expression (Eq. (32)) it is evident that the precipitation and dissolution of $\mathrm{MgCO}_{3}$ has the same effect on DIC and TA as that of $\mathrm{CaCO}_{3}$.

\subsection{Electroneutrality and uptake of nutrients by algae}

Many nutrients in seawater exist in the form of ions $\left(\mathrm{HCO}_{3}^{-}, \mathrm{NO}_{3}^{-}, \mathrm{NH}_{4}^{+}, \mathrm{HPO}_{4}^{2-}, \mathrm{H}_{3} \mathrm{SiO}_{4}^{-}, \ldots\right)$. In order to keep electroneutrality inside the cell, algae have to take up charged nutrient species by cotransport or exchange of ions: either transporting negative and positive ions in the same direction (symport) or transporting ions of the same sign in opposite directions (antiport). Because most of the charged nutrient species are anions and because the cell demands respect stoichiometric constraints ('Redfield ratios'; Redfield, 1934; Redfield
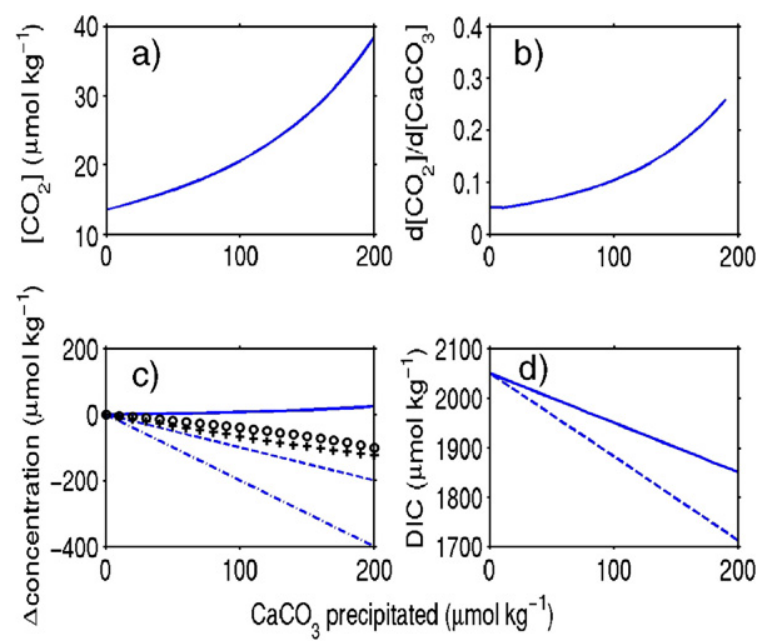

Fig. 4. Changes of the carbonate system due to precipitation of $\mathrm{CaCO}_{3}$. Initial conditions: $\mathrm{DIC}=2050 \mu \mathrm{mol} \mathrm{kg} \mathrm{kg}^{-1}, \mathrm{TA}=2300 \mu \mathrm{mol} \mathrm{kg} \mathrm{k}^{-1}$, $S=35, T=15^{\circ} \mathrm{C} \Rightarrow \mathrm{pCO}_{2}=361 \mu \mathrm{atm}$. a) Closed system: $\left[\mathrm{CO}_{2}\right]$ increases with $\mathrm{CaCO}_{3}$ precipitation. b) Closed system: the change of $\left[\mathrm{CO}_{2}\right]$ per mole of $\mathrm{CaCO}_{3}$ precipitated, $\mathrm{d}\left[\mathrm{CO}_{2}\right] / \mathrm{d}\left[\mathrm{CaCO}_{3}\right]$, increases with decreasing concentration of carbonate ion. c) Closed system: changes in $\left[\mathrm{CO}_{2}\right]$ (solid line), DIC (dashed line), TA (dash-dotted line), $\left[\mathrm{HCO}_{3}^{-}\right](\mathrm{o})$, and $\left[\mathrm{CO}_{3}^{2-}\right](+)$. d) DIC decreases with $\mathrm{CaCO}_{3}$ precipitation in the closed system (solid line) but even more in the open system (dashed line). et al., 1963), electroneutrality has to be established by cotransport or exchange with non-nutrient ions.

In erythrocytes, which together with blood plasma transport $\mathrm{CO}_{2}$ from respiration in tissue to the lungs where it leaves the body, $\mathrm{HCO}_{3}^{-}$and $\mathrm{Cl}^{-}$are exchanged. This exchange cancels over a full cycle of blood between tissue and lungs because the exchange goes both ways with the same amount in each direction (Fig. 5).

On the contrary, in photoautotrophs, salt ions cannot be used for this purpose because after a while all ions of a certain species $\left(\mathrm{Cl}^{-}\right.$, for example) would be expelled from the cell or the cellular concentration of certain species $\left(\mathrm{Na}^{+}\right.$, for example) would be ever increasing as most nutrients are negatively charged.

If charge compensation between different nutrient species and with salt ions is ruled out in microalgae, one is left with compensation by transport of $\mathrm{H}^{+}$or $\mathrm{OH}^{-}$. Experimentally, it can be very difficult to discern between $\mathrm{H}^{+}$or $\mathrm{OH}^{-}$pumps, but the existence of proton pumps is well established. In what follows we will speak only of proton pumps while keeping in mind that an $\mathrm{OH}^{-}$pump in the opposite direction would have the same effect on the charge balance.

Based on the arguments presented above, one arrives at the conclusion that deviations from electroneutrality due to the uptake of charged nutrient species have to be compensated by pumping protons in the appropriate direction. More complex transport pathways may be possible. $\mathrm{NO}_{3}^{-}$could be co-transported via a symport with $\mathrm{Na}^{+}$, for example. It is known that some porter systems are Na-dependent (Hildebrand et al., 1997; Boyd and Gradmann, 1999). In order to avoid unlimited accumulation of $\mathrm{Na}^{+}$inside the cell, however, the sodium ions have to be disposed of; this can be achieved by exchange with $\mathrm{H}^{+}$via an antiport. The net effect is cotransport of $\mathrm{NO}_{3}^{-}$with $\mathrm{H}^{+}$. The same reasoning applies also for other charged nutrient species. We will refer to this as the 'nutrient- $\mathrm{H}^{+}$-compensation principle'.

In the following we will assume that the nutrient$\mathrm{H}^{+}$-compensation principle always applies. The combination of this principle with the explicit conservative expression for TA will allow us to derive in a simple way the changes of total alkalinity due to nutrient assimilation.

\subsection{Nitrogen assimilation and remineralization, nitri- fication, denitrification}

\subsection{1. $N$ assimilation}

Marine photoautotrophs can use nitrate $\left(\mathrm{NO}_{3}^{-}\right)$, nitrite $\left(\mathrm{NO}_{2}^{-}\right)$, ammonia $\left(\mathrm{NH}_{4}^{+}\right)$, or molecular nitrogen $\left(\mathrm{N}_{2}\right)$ as a 
Tissue capillary

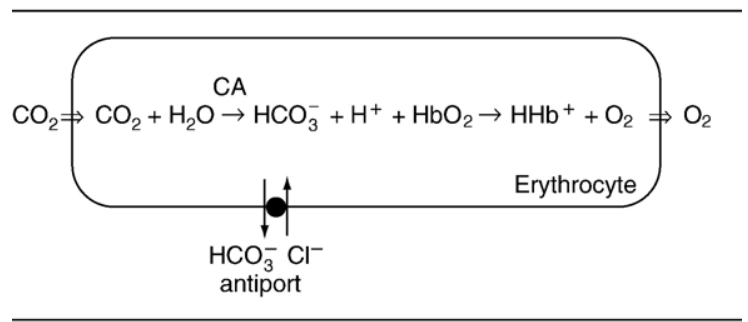

Lung capillary

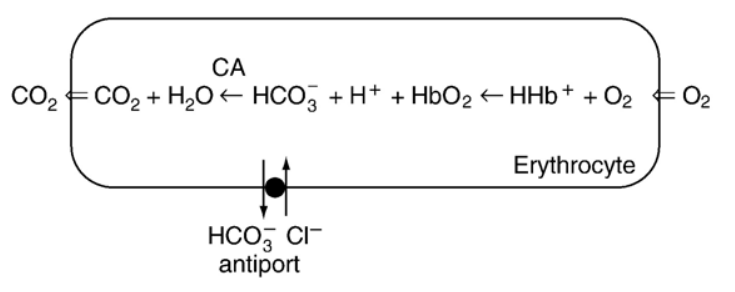

Fig. 5. Exchange (antiport) of $\mathrm{HCO}_{3}^{-}$and $\mathrm{Cl}^{-}$in erythrocytes (after Weiss, 1996). $\mathrm{CO}_{2}$ from respiration in tissue enters the erythrocyte by diffusion (upper half, left; the oval line denotes the cell membrane of the erythrocyte), is converted to $\mathrm{HCO}_{3}^{-}$(catalyzed by the enzyme carbonic anhydrase (CA)), and is transported via an antiport (exchange with $\mathrm{Cl}^{-}$, so-called Hamburger shift) into the blood plasma in the form of $\mathrm{HCO}_{3}^{-}$. $\mathrm{H}^{+}$binds to the hemoglobin- $\mathrm{O}_{2}$ complex $\left(\mathrm{HbO}_{2}\right)$ and causes release of $\mathrm{O}_{2}$ which leaves the cell by diffusion (upper half, right). Part of the $\mathrm{CO}_{2}$ entering the cell binds with the hemoglobin- $\mathrm{O}_{2}$ complex and also causes release of $\mathrm{O}_{2}$ (not shown here). $\mathrm{O}_{2}, \mathrm{H}^{+}$, and $\mathrm{CO}_{2}$ bind to different sites of the hemoglobin molecule. In the lungs, the high oxygen concentration leads to the formation of hemoglobin- $\mathrm{O}_{2}$ complexes and release of $\mathrm{H}^{+}$. $\mathrm{HCO}_{3}^{-}$enters the erythrocyte from the blood plasma (lower half, right) via an antiport (exchange with $\mathrm{Cl}^{-}$). It is converted inside the cell to $\mathrm{CO}_{2}$ (catalyzed by carbonic anhydrase) which leaves the cells by diffusion (lower half, left). Over a full cycle between tissue and lungs the same amount of $\mathrm{HCO}_{3}^{-}$and $\mathrm{Cl}^{-}$enters and leaves the cell and therefore there is no net accumulation or loss of $\mathrm{Cl}^{-}$ by the erythrocyte.

nitrogen source. From the nutrient- $\mathrm{H}^{+}$-compensation principle and the expression for $\mathrm{TA}_{\mathrm{ec}}$ (Eq. (32)) it immediately follows that the assimilation of 1 mole of nitrogen (atoms) leads to (i) an increase of alkalinity by 1 mole when nitrate or nitrite is the $\mathrm{N}$ source, (ii) to a decrease of alkalinity by 1 mole when ammonia is used, and (iii) to no change of alkalinity when molecular nitrogen is the $\mathrm{N}$ source (cellular fixation of $\mathrm{N}_{2}$ by cyanobacteria such as Trichodesmium). Indeed, these alkalinity changes for the uptake of nitrate or ammonia, respectively, have been observed in experiments by Brewer and Goldman (1976) and Goldman and Brewer (1980).

\subsubsection{Remineralization}

Remineralization of particulate organic matter (including cyanobacteria) will change TA depending on the form of reactive nitrogen produced. A release of 1 mole of ammonia or nitrate will lead to an increase or decrease, respectively, of TA by 1 mole (Eq. (32)).

\subsubsection{Nitrification}

In an aerobic environment, ammonia is ultimately oxidized to nitrate. Nitrification according to (Schlesinger, 1997)

$$
\begin{aligned}
& \mathrm{NH}_{4}^{+}+\frac{3}{2} \mathrm{O}_{2} \Rightarrow \mathrm{NO}_{2}^{-}+\mathrm{H}_{2} \mathrm{O}+2 \mathrm{H}^{+} \\
& \Delta \mathrm{TA}=-2 \quad \text { moles per mole } \mathrm{NH}_{4}^{+} \\
& \mathrm{NO}_{2}^{-}+\frac{1}{2} \mathrm{O}_{2} \Rightarrow \mathrm{NO}_{3}^{-} \quad \Delta \mathrm{TA}=0
\end{aligned}
$$

leads to a decrease of TA by 2 moles per mole of $\mathrm{NO}_{3}^{-}$ formed (Eq. (32)).

\subsubsection{Nitrogen fixation followed by remineralization and nitrification}

Nitrogen fixation followed by remineralization and nitrification converts dissolved $\mathrm{N}_{2}$ to nitrate. Cellular fixation of $\mathrm{N}_{2}$ by itself does not change total alkalinity. Upon release of nitrogen in the form of $\mathrm{NH}_{4}^{+}$TA increases by 1 mole per mole N. Nitrification (conversion of $\mathrm{NH}_{4}^{+}$to $\mathrm{NO}_{3}^{-}$) decreases TA by 2 moles per mole $\mathrm{N}$. Thus a decrease of TA by 1 mole per mole $\mathrm{N}$ fixed is the ultimate consequence of nitrogen fixation followed by remineralization and nitrification.

The global rate of marine nitrogen fixation has been estimated to be $110 \mathrm{Tg} \mathrm{N} \mathrm{a}{ }^{-1}$ or $8 \mathrm{Tmol} \mathrm{N} \mathrm{a}^{-1}$ (Deutsch et al., 2001) and thus the associated rate in TA decrease is $8 \mathrm{Tmol} \mathrm{a}^{-1}$. To set this number into perspective we estimate the TA flux due to a global new production of $10 \mathrm{Pg} \mathrm{C} \mathrm{a}^{-1}$. If this new production is based on nitrate uptake, the nitrate flux can be estimated as $10 \mathrm{Pg} \mathrm{C} \mathrm{a}^{-1} /\left(12 \mathrm{~g} \mathrm{~mol}^{-1}\right) /(6.6 \mathrm{~mol} \mathrm{C}$ $\left.(\mathrm{mol} \mathrm{N})^{-1}\right) \approx 100 \mathrm{Tmol} \mathrm{N} \mathrm{a}^{-1}$ which corresponds to a TA flux of $100 \mathrm{Tmol} \mathrm{a}^{-1}$. Thus the change of TA due to nitrogen fixation followed by remineralization is $8 \%$ of the TA flux associated with nitrate uptake in new production; locally the relative contribution by nitrogen fixation may be much larger.

\subsubsection{Denitrification}

In steady state, the input of reactive nitrate by nitrogen fixation is balanced by denitrification which can be described by (Schlesinger, 1997)

$$
\begin{aligned}
5 \mathrm{CH}_{2} \mathrm{O}+4 \mathrm{H}^{+}+4 \mathrm{NO}_{3}^{-} \Rightarrow & 2 \mathrm{~N}_{2}+5 \mathrm{CO}_{2} \\
& +7 \mathrm{H}_{2} \mathrm{O}
\end{aligned}
$$


and which leads to an increase of TA by 1 mole per mole of nitrate converted (Eq. (32)) thus balancing the corresponding alkalinity decrease. However, because $\mathrm{N}_{2}$ fixation and denitrification occur in different areas of the world ocean these processes will affect the spatial distribution of TA.

\subsection{Phosphorus assimilation and remineralization}

Uptake of 1 mole of phosphate $\left(\mathrm{H}_{3} \mathrm{PO}_{4}, \mathrm{H}_{2} \mathrm{PO}_{4}^{-}\right.$, $\mathrm{HPO}_{4}^{2-}$, or $\mathrm{PO}_{4}^{3-}$ ) by algae in accordance with the nutrient- $\mathrm{H}^{+}$-compensation principle increases alkalinity by 1 mole per mole $\mathrm{P}$ (compare the term $\mathrm{TPO}_{4}$ in Eq. (32)). Please note that the change of TA is independent of the phosphate species taken up by the cell; contrary statements can be found in the literature without convincing support.

Marine plankton contain $\mathrm{C}, \mathrm{N}, \mathrm{P}$ in the molar ratios of 106:16:1 (mean values, according to Redfield et al., 1963) and thus the effect on TA of phosphate uptake by algae is small compared to the effect of nitrate uptake. Assimilation of dissolved organic phosphate (assumed as uncharged) would have no effect on alkalinity. Release of inorganic phosphate during remineralization leads to a corresponding decrease of alkalinity.

\subsection{Silicon assimilation and remineralization}

Although $\mathrm{H}_{3} \mathrm{SiO}_{4}^{-}$contributes to TA (Eq. (28)), uptake of silicic acid by diatoms does not change TA. Uptake of $\mathrm{H}_{4} \mathrm{SiO}_{4}$ leads to changes in $\left[\mathrm{H}_{3} \mathrm{SiO}_{4}^{-}\right]$(due to re-equilibration in the silicic acid system) and also in pH. Uptake of $\mathrm{H}_{3} \mathrm{SiO}_{4}^{-}$has to be accompanied by $\mathrm{H}^{+}$ uptake and also leads to changes in $\mathrm{pH}$. From these considerations alone it is not possible to estimate the possible change in TA. In Eq. (32), however, no silicon compound or total concentration shows up and thus uptake of silicic acid by diatoms or remineralization of silica does not change TA.

\subsection{Sulfur assimilation and remineralization}

Sulfur is an essential component of proteins and it is contained in the amino acids cysteine and methionine. The molar sulfur to phosphorus ratio, S:P, in marine organic matter varies between 2.4:1 for Skeletonema costatum (diatom) and 3.3:1 for Emiliania huxleyi (coccolithophore) and for Prorocentrum minimum (dinoflagellate); according to ratios calculated from C:S ratios after Matrai and Keller (1994) assuming the classical Red-field ratio $\mathrm{C}: \mathrm{P}=106: 1$. Uptake of sulfate in accordance with the nutrient- $\mathrm{H}^{+}$-compensation principle and assimilation into particulate organic matter leads to an increase of alkalinity by 2 moles per mole of $\mathrm{S}$ (compare the term $2 \mathrm{TSO}_{4}$ in Eq. (32)). This effect has been mentioned already by Brewer et al. (1975) and discussed in detail by Chen (1978). Release of sulfate during remineralization leads to a corresponding decrease of alkalinity.

\subsection{Overall effect of production by marine plankton}

Following Chen (1978) we will now express the change of alkalinity as a function of the amount of $\mathrm{CaCO}_{3}$ precipitation, $\Delta \mathrm{Ca}(\mathrm{mol})$, and amount of particulate organic matter produced (measured in units of $\mathrm{POP}=$ Particulate Organic Phosphorus, mol P, or $\mathrm{PON}=$ Particulate Organic Nitrogen, mol N). We assume that nitrate, phosphate and sulfate are the nutrient sources with ratios to carbon as $\mathrm{C}: \mathrm{N}: \mathrm{P}: \mathrm{S}=$ 106:16:1:2.4 and that no other carbonates than $\mathrm{CaCO}_{3}$ are precipitated. Note that the algal uptake of silicic acid $\left(\mathrm{H}_{4} \mathrm{SiO}_{4}\right.$ or $\left.\mathrm{H}_{3} \mathrm{SiO}_{4}^{-}\right)$in accordance with the nutrient- $\mathrm{H}^{+}$. compensation principle has no effect on TA. The overall change in alkalinity is

$\Delta \mathrm{TA}=2 \Delta \mathrm{Ca}-21.8 \mathrm{POP}=2 \Delta \mathrm{Ca}-1.36 \mathrm{PON}$

where the factor $21.8=16+1+2 \cdot 2.4$ stems from nitrate uptake $(+16 ; \mathrm{N}: \mathrm{P}=16)$, phosphate uptake $(+1)$, and sulphate uptake $(+2.4 \cdot 2 ; \mathrm{S}: \mathrm{P}=2.4$; factor 2 stems from $2 \mathrm{TSO}_{4}$ in Eq. (32)). The effect of sulfur is more important (4.8:1) than that of phosphorus.

Conversely, the change of calcium can be predicted from the changes of alkalinity and nitrate according to

$\Delta \mathrm{Ca}=0.5 \Delta \mathrm{TA}+0.68 \Delta \mathrm{NO}_{3}^{-}$

where (again assuming $\mathrm{N}: \mathrm{P}=16: 1$ ) 21.8/2/16 $\approx 0.68$. Based on a different $\mathrm{S}: \mathrm{C}$ ratio Kanamori and Ikegami (1982) gave a factor 0.63 instead of 0.68 . These authors found good agreement of these predictions with very precise measurements of $\left[\mathrm{Ca}^{2+}\right]$ in the Pacific.

\subsection{Methane oxidation by sulphate reduction}

In anoxic sediments methane can be oxidized by sulphate reduction:

$\mathrm{CH}_{4}+\mathrm{SO}_{4}^{2-} \rightarrow \mathrm{HCO}_{3}^{-}+\mathrm{HS}^{-}+\mathrm{H}_{2} \mathrm{O}$.

The products react with $\mathrm{H}^{+}$and therefore it can be difficult to derive the change in TA from the right-hand side of the formula. From the left-hand side, however, it is 
clear that the concentration of total sulphate decreases by 1 mole per mole of methane oxidized and thus TA is increased by 2 moles per mole of methane oxidized according to Eq. (32). Please note that the decrease of methane concentration has no effect on TA. DIC increases by 1 mole per mole of $\mathrm{CH}_{4}$ oxidized. The change of $\mathrm{pH}$ (increase) can be calculated using TA and DIC.

\section{The alkalinity definition by Peng et al. (1987)}

Peng et al. (1987) define alkalinity by the following expression (we have replaced $\mathrm{H}_{2} \mathrm{BO}_{3}^{-}$by $\mathrm{B}(\mathrm{OH})_{4}^{-}$)

$$
\begin{aligned}
A_{\text {Peng }}= & {\left[\mathrm{HCO}_{3}^{-}\right]+2\left[\mathrm{CO}_{3}^{2-}\right]+\left[\mathrm{B}(\mathrm{OH})_{4}^{-}\right] } \\
& +\left[\mathrm{OH}^{-}\right]+\left[\mathrm{H}_{2} \mathrm{PO}_{4}^{-}\right]+2\left[\mathrm{HPO}_{4}^{2-}\right] \\
& +3\left[\mathrm{PO}_{4}^{3-}\right]+\left[\mathrm{H}_{3} \mathrm{SiO}_{4}^{-}\right]-\left[\mathrm{H}^{+}\right] .
\end{aligned}
$$

This definition encompasses charged species only and the prefactors of each ion concentration is equal to -1 times the ionic charge (for example, $3\left[\mathrm{PO}_{4}^{3-}\right]$ ). This definition is 'correct' in the sense that one can do meaningful calculations based on this quantity. Unfortunately, Peng's definition is not compatible with Dickson's definition of titration alkalinity. For instance, even if one neglects contributions by minor species such as $\mathrm{NH}_{3}$ etc. in (Eq. (28)), Dickson's expression reads:

$$
\begin{aligned}
\mathrm{TA}= & {\left[\mathrm{HCO}_{3}^{-}\right]+2\left[\mathrm{CO}_{3}^{2-}\right]+\left[\mathrm{B}(\mathrm{OH})_{4}^{-}\right]+\left[\mathrm{OH}^{-}\right] } \\
& +\left[\mathrm{HPO}_{4}^{2-}\right]+2\left[\mathrm{PO}_{4}^{3-}\right] \\
& \left.+\left[\mathrm{H}_{3} \mathrm{SiO}_{4}^{-}\right]-\left[\mathrm{H}^{+}\right]-\left[\mathrm{HSO}_{4}^{-}\right]-\mathrm{H}_{3} \mathrm{PO}_{4}\right]
\end{aligned}
$$

which is different (by $\mathrm{TPO}_{4}$ ) from Eq. (41). This difference is due to a different choice of Peng et al. for the zero level of protons for phosphoric acid $\left(\mathrm{H}_{3} \mathrm{PO}_{4}\right.$ instead of $\left.\mathrm{H}_{2} \mathrm{PO}_{4}^{-}\right)$. A counter-intuitive consequence of this choice of zero level of protons is that the alkalinity of a seawater sample will not change when phosphoric acid is added to it. Furthermore, there is scope for significant confusion resulting from the existence of two definitions. Calculations of fugacities (or partial pressures) of $\mathrm{CO}_{2}$ based on the same values of alkalinity (but not same definition!) and DIC will lead to different results depending on the concentration of total phosphate: the difference in $\mathrm{pCO}_{2}$ is $\approx 1.6 \mu \mathrm{atm}$ per $\mu \mathrm{mol} \mathrm{kg} \mathrm{kg}^{-1}$ phosphate. Such differences may be negligible for surface water conditions but may be significant in deeper water or in laboratory experiments with nutrient enriched water.

\section{Summary and conclusion}

Although the definition of total alkalinity by "TA is the excess of proton acceptors over proton donors with respect to a certain zero level of protons" is a simple one, it is a difficult concept to grasp because many other concepts (acid-base, equilibrium constants, zero level of protons, proton condition, gravimetric units) are required to understand it and its consequences. The exact definition of TA given by Dickson (1981) using zero level of protons and selecting $\mathrm{pK}_{\mathrm{zlp}}=4.5$ provides an expression for TA of natural water samples in terms of chemical species which are individually non-conservative although their sum is a conservative quantity. Electroneutrality of aqueous solutions can be used to derive an expression for TA in terms of concentrations of conservative ions and of total concentrations of phosphate, ammonia, sulphate, fluoride, and nitrite from Dickson's definition of TA. In contrast to Dickson's expression, each term in the newly derived expression is conservative. This explicitly conservative form of total alkalinity, $\mathrm{TA}_{\mathrm{ec}}$, is equivalent to Dickson's expression for TA. The $\mathrm{TA}_{\mathrm{ec}}$ can be used to derive the changes in total alkalinity due to various biogeochemical processes in an easy way (Section 5).

\section{Acknowledgements}

We like to thank Prof. Gerhard Thiel (Darmstadt) for discussions about proton versus $\mathrm{OH}^{-}$pumps and Silke Thoms for critical reading of an earlier version of the manuscript. Comments by Hein de Baar and an anonymous reviewer led to improvements of the article. D.A. Wolf-Gladrow, C. Klaas, and A. Körtzinger were supported by the European Commission (GOCE511176, EU FP6 IP CarboOcean). The research was supported by DOE grant DE-FG02-06ER64077 to Richard E. Zeebe. A. Dickson was supported by the US National Science Foundation (OCE 0137287).

\section{References}

Boyd, Gradmann, 1999. Electrophysiology of the marine diatom Coscinodiscus wailesii. III. Uptake of nitrate and ammonium. J. Exp. Bot. 50 (333), 461-467.

Brewer, P.G., Goldman, J.C., 1976. Alkalinity changes generated by phytoplankton growth. Limnol. Oceanogr. 21 (1), 108-117.

Brewer, P.G., Wong, G.T., Bacon, M.D., Spencer, D., 1975. An oceanic calcium problem? Earth Planet. Sci. Lett. 26, 81-87.

Brønsted, J.N., 1923. Einige Bemerkungen über den Begriff der Säuren und Basen. Recl. Trav. Chim. Pays-Bas 42, 718-728.

Chen, C.-T.A., 1978. Decomposition of calcium carbonate and organic carbon in the deep oceans. Science 201, 735-736.

Deutsch, C., Gruber, N., Key, R.M., Sarmiento, J.L., Ganachaud, A., 2001. Denitrification and $N_{2}$ fixation in the Pacific Ocean. Glob. Biogeochem. Cycles 15 (2), 483-506.

Dickson, A.G., 1981. An exact definition of total alkalinity and a procedure for the estimation of alkalinity and total inorganic carbon from titration data. Deep-Sea Res. 28A (6), 609-623. 
Dickson, A.G., 1992. The development of the alkalinity concept in marine chemistry. Mar. Chem. 40 (1-2), 49-63.

DOE, 1994. Handbook of methods for the analysis of the various parameters of the carbon dioxide system in sea water. Version 2. In Dickson, A.G., Goyet, C. (Eds.), ORNL/CDIAC-74.

Friis, K., Körtzinger, A., Wallace, D.W.R., 2003. The salinity normalization of marine inorganic carbon chemistry data. Geophys. Res. Lett. 30 (2), 1085. doi:10.1029/2002GL015898.

Goldman, J.C., Brewer, P.G., 1980. Effect of nitrogen source and growth rate on phytoplankton mediated changes in alkalinity. Limnol. Oceanogr. 25, 352-357.

Hildebrand, M., Volcani, B.E., Gassmann, W., Schroeder, J.I., 1997. A gene family of silicon transporters. Nature 385, 688-689.

Jacobsen, O., 1873. Ueber die Luft des Meerwassers. Justus Liebig's Ann. Chem. Pharm. 167, 1-38.

Kanamori, S., Ikegami, H., 1982. Calcium-alkalinity relationship in the North Pacific. J. Oceanogr. Soc. Jpn. 38, 57-62.

Kim, H.-C., Lee, K., Choi, W., 2006. Contribution of phytoplankton and bacterial cells to the measured alkalinity of seawater. Limnol. Oceanogr. 51 (1), 331-338.

Lowry, T.M., 1923a. The uniqueness of hydrogen. Chem. Ind. (Lond.) $42,43-47$.

Lowry, T.M., 1923b. Coordination and acidity. Chem. Ind. (Lond.) 42, $1048-1052$.

Matrai, P.A., Keller, M.D., 1994. Total organic sulfur and dimethylsulfoniopropionate in marine phytoplankton: intracellular variations. Mar. Biol. 119 (1), 61-68.
Peng, T.-H., Takahashi, T., Broecker, W.S., Olafsson, J., 1987. Seasonal variability of carbon dioxide, nutrients and oxygen in the northern North Atlantic surface water: observations and a model. Tellus 39B, 439-458.

Rakestraw, N.W., 1949. The concept of alkalinity or excess base of sea water. J. Mar. Res. 8, 14-20.

Redfield, A.C., 1934. On the proportions of organic derivatives in sea water and their relation to the composition of plankton. James Johnstone Memorial Volume, Liverpool, pp. 177-192.

Redfield, A.C., Ketchum, B.H., Richards, F.A., 1963. The influence of organisms on the composition of seawater. In: Hill, M.N. (Ed.), The Sea, vol. 2. Interscience, New York, pp. 1-34.

Schlesinger, W.H., 1997. Biogeochemistry: An Analysis of Global Change, 2nd ed. Academic Press, San Diego. 588 pp.

Watanabe, A., Kayanne, H., Nozaki, K., Kato, K., Negishi, A., Kudo, S., Kimoto, H., Tsuda, M., Dickson, A.G., 2004. A rapid, precise potentiometric determination of total alkalinity in seawater by a newly developed flow-through analyzer designed for coastal regions. Mar. Chem. 85, 75-87.

Weiss, T.F., 1996. Cellular Biophysics, Volume 1: Transport. MIT Press, Cambridge, Mass.

Zeebe, R.E., Wolf-Gladrow, D., 2001. $\mathrm{CO}_{2}$ in seawater: equilibrium, kinetics, isotopes. Elsevier Oceanography Series, vol. 65. 346 pp., Elsevier, [second printing 2003]. 